\title{
Orofaciodigital syndrome type 2
}

INSERM

\section{Source}

INSERM. (1999). Orphanet: an online rare disease and orphan drug data base.

Orofaciodigital syndrome type 2. ORPHA:2751

Oral-facial-digital (OFD) type 2 is characterized by hand and feet deformities, facial deformities, midline cleft of the upper lip and tongue hamartomas. 